\title{
Yield Potential of Wheat (Triticum aestivum) and Faba Bean (Vicia faba) Mixed Intercropping in Western Shoa
}

\author{
Fikadu Kumsa ${ }^{1}$, Lakew Wondimu ${ }^{1}$, Tadesse Debele ${ }^{2}$ \\ ${ }^{1}$ Department of Biology, College of Natural and Computational Science, Ambo University, Ethiopia \\ ${ }^{2}$ Department of Plant Sciences, College of Agriculture and Veterinary Sciences, \\ Ambo University, Ethiopia
}

\begin{abstract}
Intercropping is the growing of two (or more) crops together on the same piece of land and often possess an advantage in terms of more yield and less use of plot of land compared to sole cropping. Some crop varieties may not fix environmental nitrogen hence they need application of more chemical fertilizers. Thus, intercropping may be chosen to alleviate a particular limitation of soil nitrogen resources. In this study, effect of intercropping systems of feba bean and wheat on yield of wheat in Ambo area, West Shoa, Ethiopia have been investigated. Experiments were conducted at Guder and Ginchi. The experiment was laid out in a randomized complete block designs (RCBD) with three replications. The treatments were sole wheat, sole faba bean, mix and alternate cropping systems. Results of the investigation showed that the highest wheat yield at Guder was $1420.8 \mathrm{Kg} \mathrm{ha}^{-1}$ and Ginchi was $1185.8 \mathrm{Kg} \mathrm{ha}^{-1}$ was obtained when wheat was intercropped alternatively with faba bean. Similarly, mix intercropped possesses significant wheat yield $1174 \mathrm{Kg} \mathrm{ha}^{-1}$ ) and $1013.3 \mathrm{Kg} \mathrm{ha}^{-1}$ at Guder and Ginchi sites, respectively. But the lowest yield was obtained from sole wheat at Ginchi $\left(790 \mathrm{Kg} \mathrm{ha}^{-1}\right)$ and Guder (1061 Kg ha $\left.\mathrm{Ka}^{-1}\right)$ sites. At the two sites, the land equivalent ratio (LER>2) signify the tested cropping system approach is very much useful as it increase the yield on mix and alternate intercropped systems than the sole cropping.
\end{abstract}

Keywords: Biomass, Faba Bean, Intercropping System, Nitrogen, Tiller, Wheat, Yield.

\section{INTRODUCTION}

Intercropping is the growing of two (or more) crops together on the same piece of land and often produces an advantage in terms of more yield and less use of plot of land when comparable to sole crops (Bulson et al., 1996). According to Eskandari and Ghanbari (2010), intercropping is important practice for the development of sustainable food as it has a potential benefits for high productivity and profitability, improvement of soil fertility through the addition of nitrogen and efficient use of environmental resources through the complementary effects of two or more crops. In addition, in legume intercrop, there is nitrogen leaching from the legume to the associate crop and it provide free supply of 15-20 units of nitrogen per month during growing season due to nitrogen fixation (Issahaku, 2010). The more efficient use of limiting resources in intercropping can occur because the component crops use the resources either at different times, in different parts of the soil or in different forms (Eskandari and Ghanbari, 2010).

Intercropping was also adapted as mixtures of forage species on organic farming systems. Mixtures of wheat and beans were traditionally grown in Britain, but differences in the maturity date and harvesting were the problems. The introduction of the combine harvester has resulted in the demise of this practice (Bulson et al., 1996). However, early maturing bean varieties are now available, which may allow wheat and beans to be harvested together. The resulting mixture can then either be separated after harvest, using seed cleaning equipment, or be fed to livestock as a mixture (Bulson et al., 1996). The study done on wheat/maize and wheat/soybean intercropping systems indicate that, a significant yield was obtained from intercropped wheat over sole wheat (Eskandari and Ghanbari, 2010). Even though intercropping has been started as one of the multiple cropping systems by ancient farmers for many years in various ways, it is one of the best technologies in china and other countries today (Bulson et al., 1996).

Most studies on intercropping have focused on the legume-cereal intercropping to know the nitrogen input from symbiotic nitrogen fixation into the cropping system and reduction of negative impacts on the environment. The reason of yield advantage of intercropping are mainly that environmental 
resources such as water, light and nutrients can be utilized more efficiently in intercropping than in the respective sole cropping systems (Eskandari and Ghanbari, 2010).

The underlying principle of better environmental resource use in intercropping is that if crops differ in the way they utilize resources when grown together, they can complement each other and make better combined use of resources than they grown separately (Eskandari and Ghanbari, 2010).

According to Morgan (2005), some crop varieties may not fix the environmental nitrogen rather they need in the form of prepared fertilizers. So intercropping is so much needed to alleviate a particular limitation of resources in the soil. Even though intercropping is generally associated with small land holdings and to minimize Nitrogen fertilizer application, the amount of nitrogen is determined by the crop type, and quantity of nitrogen that might be provided by the soil. Thus, the amount of atmospheric nitrogen fixed by non-symbiotic and legume symbiotic soil organisms vary with soil types, region and types of plant varieties (Eskandari and Ghanbari, 2010).

In addition intercropping can reduce soil erosion and also the effect of pests. Timing has also a major effect on the efficiency of nitrogen management systems. The aim of this study was to investigate the effect of intercropping of wheat variety with Faba bean on yield potential of wheat and Faba bean here by comparing the obtained yields among intercropped and the sole cropping. Additionally, the best spatial arrangements for enhancing productivity of Faba bean-wheat intercropping systems were also identified.

\section{Materials AND Methods}

\subsection{Description of the Study Area}

The field experiments were carried out in western Shoa at Ginchi and Guder during main cropping season of 2012-2013. The study sites were located in West Shoa zone of Oromia National Regional State, central Ethiopia. Ginchi research site is located at $85 \mathrm{~km}$ West of Addis Ababa while Guder Production Farm is located at $124 \mathrm{~km}$, West of Addis Ababa at an altitude of 2200 and 1800 above mean sea level, respectively. The soil type of Ginchi research site is Vertisols with pH of 6.5 at soil depth of 0 to $30 \mathrm{~cm}$. Slope of the study site is ranges from 2 to $5 \%$. On the other hand, the soil type of Guder Production Farm is Nitosol with soil pH of 5.5 to 6.0 at similar soil depth.

Both study areas have a unimodal rainfall pattern and average annual total rainfall ranging between $800-1260 \mathrm{~mm}$. The annual (2012-2013) mean minimum, maximum and average air temperatures are $8.91,25.0$ and $18.37{ }^{\circ} \mathrm{C}$, respectively.

\subsection{Experimental Design and Treatments}

The experiments were laid out in a randomized complete block designs (RCBD) with three replications. The treatments were composed of four cropping systems of sole wheat, sole faba bean, mix and alternate at two locations. All agronomic practices were undertaken. The improved wheat variety and Faba bean) were sown in drill at a seed rate of $175 \mathrm{~kg} \mathrm{ha}^{-1}$ and $200 \mathrm{~kg} \mathrm{ha}^{-1}$, respectively (Getachew et al., 2008). Detailed information of yield-crop spatial arrangements relationship during intercropping were investigated and recorded.

\subsection{Data Collection and Analysis}

The collected data includes plant height, dry biomass, number of tillers and grain yield. Collected data were subjected to analysis of variance (ANOVA). Treatments and mean differences were separated by the least significant difference (LSD) test at 0.05 probability level. All statistical analyses were performed using the SPSS version 16.0 statistical software.

\section{RESUlTS AND DisCUSSION}

\subsection{Effect of Intercropping Systems on Yield and other Growth Parameters at Guder Site}

From the different intercropped systems tested at Guder site, the best wheat yield was obtained at alternatively intercropped $\left(1420.8 \mathrm{Kg} \mathrm{ha}^{-1}\right)$. But the capacity of wheat to induce yield was reduced when sown alone $\left(1061.6 \mathrm{Kg} \mathrm{ha}^{-1}\right)$. An increment of yield was also obtained on mixed intercropped $\left(1174.2 \mathrm{Kg} \mathrm{ha}^{-1}\right)$. The maximum dry biomass and spike length of wheat was obtained at mixed and alternate inter-cropped (Table 1). Regarding the yields of Faba beans, significant yields were obtained when it was sown alone $\left(1000 \mathrm{Kg} \mathrm{ha}^{-1}\right)$ and alternatively intercropped $\left(775 \mathrm{Kg} \mathrm{ha}^{-1}\right)$. But minimum Faba bean yield was obtained from mixed intercropped $\left(672.5 \mathrm{Kg} \mathrm{ha}^{-1}\right)$. Wheat plants were shortest in the sole plot $(103 \mathrm{~cm})$. But the height of wheat increased in faba bean population in the mix $(106 \mathrm{~cm})$ 
Yield Potential of Wheat (Triticum Aestivum) and Faba Bean (Vicia Faba) Mixed Intercropping in Western Shoa

and alternate $(109 \mathrm{~cm})$ intercropped. This result revealed that, mix and alternate intercropping of wheat with Faba bean was effective in yield at Guder site (LER>2).

Table. Effect of intercropping systems on yield and other growth parameters at Guder site

\begin{tabular}{|c|c|c|c|c|c|c|}
\hline \multirow[b]{2}{*}{ Treatments } & \multicolumn{5}{|c|}{ Means Number } & \multirow[t]{2}{*}{ LER } \\
\hline & $\begin{array}{c}\text { Yield }\left(\mathrm{Kg} \mathrm{ha}^{-}\right. \\
\left.{ }_{1}\right)\end{array}$ & $\begin{array}{l}\text { Dry Biomass } \\
\left(\mathrm{Kg} \mathrm{ha}^{-1}\right)\end{array}$ & Height(cm) & Tiller No & $\begin{array}{c}\text { Spike } \\
\text { length }(\mathrm{cm})\end{array}$ & \\
\hline 1. Sole Wheat & $\begin{array}{l}1061.6 \pm \\
196 a b\end{array}$ & $1997.5 \pm 102 b$ & $103.0 \pm 0.63 \mathrm{~d}$ & $\begin{array}{l}3.7 \pm \\
0.05 \mathrm{~d}\end{array}$ & $\begin{array}{l}6.47 \pm \\
0.20 \mathrm{~b}\end{array}$ & \\
\hline 2. Sole Faba Bean & $1000 \pm 45 b$ & $1930.8 \pm 66 b$ & $134.0 \pm 0.25 a$ & $\pm 0.10 \mathrm{~b}$ & & \\
\hline \multicolumn{7}{|l|}{$\begin{array}{l}\text { 3. Alternate } \\
\text { intercropped }\end{array}$} \\
\hline Wheat & $1420.8 \pm 269 a$ & $2668.3 \pm 203 a$ & $109.0 \pm 0.23 \mathrm{c}$ & $\begin{array}{l}6.1 \pm \\
0.21 \mathrm{a}\end{array}$ & $\begin{array}{l}7.44 \pm \\
0.10 \mathrm{a}\end{array}$ & 2.04 \\
\hline Faba bean & $775 \pm 43 b$ & $1466.6 \pm 31 c$ & $130.0 \pm 2.40 b$ & $\begin{array}{l}2.8 \pm \\
0.18 \mathrm{e} \\
\end{array}$ & - & \\
\hline \multicolumn{7}{|l|}{ 4. Mix intercropped } \\
\hline Wheat & $\begin{array}{l}1174.2 \pm \\
230 \mathrm{ab}\end{array}$ & $2198.8 \pm 144 b$ & $106.0 \pm 0.28 \mathrm{~d}$ & $\begin{array}{l}2.6 \pm \\
0.16 \mathrm{e}\end{array}$ & $\begin{array}{l}7.29 \pm \\
0.50 \mathrm{a}\end{array}$ & 2.4 \\
\hline Faba bean & $672.5 \pm 35 b c$ & $1247.5 \pm 267 \mathrm{c}$ & $128.0 \pm 0.93 b$ & $\begin{array}{l}4.4 \pm \\
0.03 \mathrm{c}\end{array}$ & - & \\
\hline
\end{tabular}

The data present the mean number of yield and other growth parameters \pm standard error of the experiments. Means having the same letters in a column were not significantly different at $5 \%$ probability level.

Table 2. Analysis of variance for the effect of intercropping systems on yield of wheat at Guder site

\begin{tabular}{|l|c|l|l|l|l|}
\hline Yield(g)/plot & Sum of Squares & df & Mean Square & F & Sig. \\
\hline $\begin{array}{l}\text { Between } \\
\text { Groups }\end{array}$ & 1586436.000 & 5 & 317287.200 & 3.748 & .028 \\
\hline $\begin{array}{l}\text { Within } \\
\text { Groups }\end{array}$ & 1015964.000 & 12 & 84663.667 & & \\
\hline Total & 2602400.000 & 17 & & & \\
\hline
\end{tabular}

Variation in the yield is significant between the treatments $(\mathrm{F}=3.748, \mathrm{df}=(5,12))$.

During the first 45 days, well defined growth parameters were observed at all intercropping systems except for a slight difference (Fig 1).

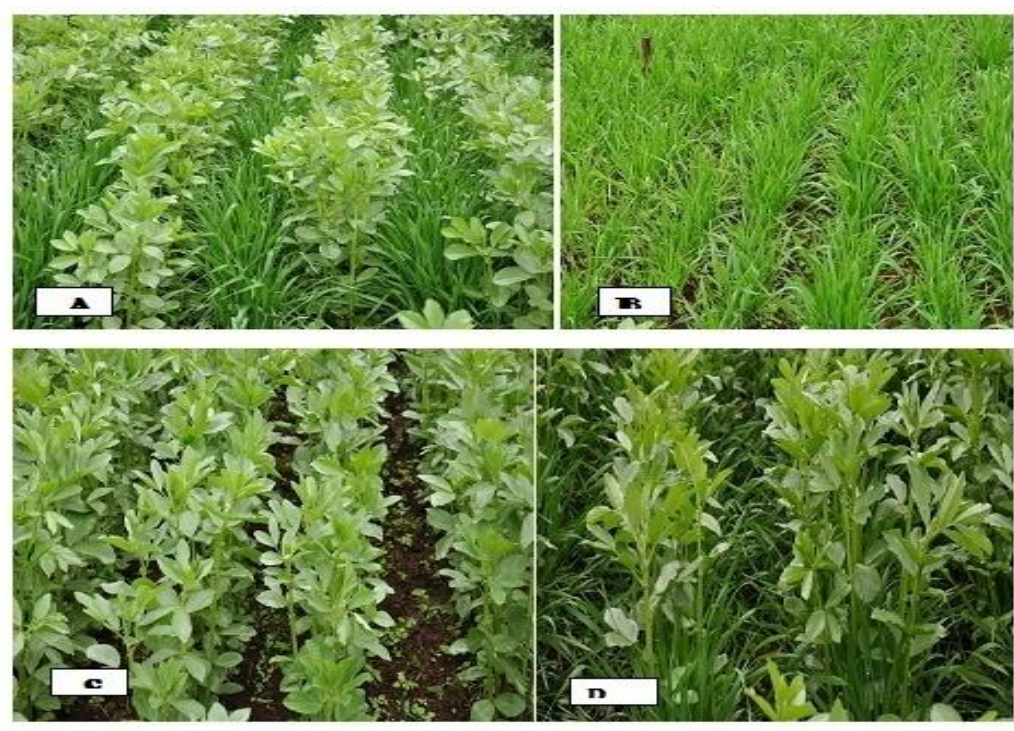

Figure 1. Intercropped systems of wheat with Faba bean at Guder Site $(\boldsymbol{A}=$ Alternate intercropped, $\boldsymbol{B}=$ Sole wheat, $\boldsymbol{C}=$ Sole Faba bean and $\boldsymbol{D}=$ Mix intercropped) from 12 July to 27 August 2012 


\subsection{Effect of Intercropping Systems on Yield and Other Growth Parameters at Ginchi Site}

Like Guder, Ginchi site also produced the best yield of wheat $\left(1185.8 \mathrm{Kg} \mathrm{ha}^{-1}\right)$ at alternate intercropped system. Likewise, significant yield was obtained from mix intercropped (1013.3 Kg ha $\left.{ }^{-1}\right)$ system of wheat. The maximum biomasses $\left(2110 \mathrm{Kg} \mathrm{ha}^{-1}\right)$ and $\left(1900.8 \mathrm{Kg} \mathrm{ha}^{-1}\right)$ were also obtained on alternate and mixed inter cropped wheat, respectively. Even though significant yield of Faba bean was obtained from sole intercropped system $\left(892.5 \mathrm{Kg} \mathrm{ha}^{-1}\right)$ non significant yields were obtained among mix and alternate intercropped systems of Faba bean.

A significantly different tiller number and spike length were also proved on mix, alternate and sole cropped systems (Table 2). The length of wheat cultivar in all cropping system was the same. But sole faba bean has shown a significant length $(88 \mathrm{~cm})$ over mix $(86 \mathrm{~cm})$ and alternate $(86 \mathrm{~cm})$ intercropped systems.

Table 3. Effect of intercropping systems on yield and other growth parameters at Ginchi site

\begin{tabular}{|c|c|l|l|l|l|l|}
\hline \multirow{2}{*}{ Treatments } & \multicolumn{5}{|c|}{ Means Number } & LER \\
\cline { 2 - 7 } & $\begin{array}{c}\text { Yield } \\
\left(\mathrm{Kg} \mathrm{ha}^{-1}\right)\end{array}$ & $\begin{array}{c}\text { Dry Biomass } \\
\left(\mathrm{Kg} \mathrm{ha}^{-1}\right)\end{array}$ & $\begin{array}{c}\text { Height } \\
(\mathrm{cm})\end{array}$ & Tiller No & $\begin{array}{c}\text { Spike } \\
\text { length }(\mathrm{cm})\end{array}$ & \\
\hline 1. Sole Wheat & $790 \pm 29 \mathrm{c}$ & $1478.3 \pm 139 \mathrm{~b}$ & $\begin{array}{l}83.0 \pm \\
0.9 \mathrm{c}\end{array}$ & $\begin{array}{l}1.7 \pm \\
0.05 \mathrm{c}\end{array}$ & $5.2 \pm 0.20 \mathrm{c}$ & \\
\hline 2. Sole Faba Bean & $892.5 \pm$ & $1694.2 \pm 73 \mathrm{~b}$ & $\begin{array}{l}88.0 \pm \\
0.5 \mathrm{a}\end{array}$ & $\begin{array}{l}2.4 \pm \\
0.11 \mathrm{~b}\end{array}$ & - & \\
\hline 3. Mix intercropped & & & & & & \\
\hline wheat & $1013.3 \pm$ & $1900.8 \pm 75 \mathrm{ab}$ & $84.0 \pm$ & $2.2 \pm$ & $5.6 \pm 0.10 \mathrm{~b}$ & 2.2 \\
& $44 \mathrm{~b}$ & & $0.5 \mathrm{c}$ & $0.09 \mathrm{~b}$ & & \\
\hline Faba bean & $608.3 \pm 96 \mathrm{~d}$ & $1005.8 \pm 115 \mathrm{c}$ & $86.0 \pm$ & $1.9 \pm$ & - & \\
& & & $0.7 \mathrm{~b}$ & $0.03 \mathrm{c}$ & & \\
\hline 4. Alternate intercropped & & & & & & \\
\hline wheat & $1185.8 \pm$ & $2110 \pm 34 \mathrm{a}$ & $85.0 \pm$ & $3.3 \pm$ & $5.9 \pm 0.10 \mathrm{a}$ & 2.1 \\
& $66 \mathrm{a}$ & & $1.0 \mathrm{c}$ & $0.20 \mathrm{a}$ & & \\
\hline Faba bean & $625 \pm 50 \mathrm{~d}$ & $1041.6 \pm 28 \mathrm{c}$ & 86.0 & $2.2 \pm$ & \\
\pm & & & $\pm 0.3 \mathrm{bc}$ & $0.09 \mathrm{~b}$ & - & \\
\hline
\end{tabular}

The data present the mean number of yield and growth parameters \pm standard error of the experiments. Means having the same letters in a column were not significantly different at 5\% probability level.

Table 4: Analysis of variance for the effect of intercropping systems on yield of wheat at Ginchi site

\begin{tabular}{|l|l|l|l|l|l|}
\hline Yield(g)/plot & Sum of Squares & df & Mean Square & F & Sig. \\
\hline Between Groups & 1097579.499 & 5 & 219515.900 & 21.254 & .000 \\
\hline Within Groups & 123941.071 & 12 & 10328.423 & & \\
\hline Total & 1221520.570 & 17 & & & \\
\hline
\end{tabular}

Variation in the yield is significant between the treatments $(\mathrm{F}=21.254, \mathrm{df}=(5,12), \mathrm{p}<0.0001)$.

Results of the investigation showed that the highest wheat yield at Guder and Ginchi was obtained when wheat was intercropped alternatively with faba bean. Thus, the yield of sole wheat was lower compared with the yield obtained from wheat-legume intercropped systems. This fact is substantiated by the research of Sarunaite et al. (2010), which indicated that sowing spring wheat with grain legume was increased production in an organic crop rotation when intercropped.

Similarly, mix intercropped possesses significant wheat yield at Guder and Ginchi sites. But the lowest yield was obtained from sole wheat at both sites. This in accordance with the report of Undie, et al., 2012, that when productivity effect was more pronounced on the late season maize/soybean mixtures.

Even though all intercropped wheat has been shown a better yield over soles, arrangements of intercropping systems did affect the yield of Faba bean at both sites. This significant yield differences among both cultivars could be the result of arrange the treatments as mix and alternate induced better yield than sole copping. Similar report has been made by (Ekram, et al., 2010) on effect of intercropping patterns on yield of Barley, Lupin or Chickpea Grown. 
Wheat plants were shortest in the sole plot. But the height of wheat increased in faba bean population in the mix and alternate intercropped. Furthermore, the faba bean plant height increased within the sole plot. This is in agreement with the report of Getachew Agegnehu et al., 2006, which reported sole height of teff were the shortest in the sole plot than the mixtures in a tropical highland environment of Ethiopia.

\section{Conclusion}

From the obtained result, it can be concluded that, mix and alternate intercropped systems, shown a significant yield of wheat over sole at both Guder and Ginchi sites. But, the best yields of wheat were obtained from alternative intercropping at both sites. An arrangement of cropping systems has been proved to have an effect on yield product of both wheat and Faba bean. The tested cropping systems approach has very much useful as it increase the yield.

\section{ACKNOWLEDGEMENT}

The authors would like to acknowledge Ambo University for financial and technical supports for the research work.

\section{REFERENCES}

[1] Asnakew W (1988) Physical Properties of Ethiopian Vertisols In Management of Sub-Saharan Africa (eds. Jutzi, S.C., Haque, I., Mclntire, J. and Stares, J.E.S.).Pp. 111-123.

[2] Attah L E (2010) Physicochemical characteristics of the rhizosphere soils of some cereal crops in Ambo Woreda, West Shoa, Ethiopia. Maejo Int. J. Sci. Technol., 4: 93-100.

[3] Bulson H A, Aydon R W and Stopes C E (1996) Effects of Plant Density on Intercropped Wheat and Beans in an Organic Farming System. J. Agr. Sci. 128:59-71.

[4] Ekram A M, Sharaan A N, EL-Sherif A M (2010) Effect of Intercropping Patterns on Yield and Its Components of Barley, Lupin or Chickpea Grown in Newly Reclaimed Soil. Egypt. J. of Appl. Sci., 25: 437-452.

[5] Eskandari H and Ghanbari A (2010) Effect of Different Planting Pattern of Wheat (Triticum aestivum) and Bean (Vicia faba) on Grain Yield, Dry Matte Production and Weed Biomass. Not Sci Biol 2: 111-115.

[6] Getachew Agegnehu, Amare Ghizaw and Woldeyesus Sinebo (2006) Crop Productivity and Land-Use Efficiency of a Teff/Faba bean Mixed Cropping System in a Tropical Highland Environment. Expl Agric. 42: 495-504.

[7] Getachew Agegnehu, Amare Ghizaw and Woldeyesus Sinebo (2008) Yield potential and Landuse Efficiency of Wheat and Faba Bean Mixed Iintercropping. Agron. Sustain. Dev. 28: 257263.

[8] Issahaku A R (2010) Spatial Arrangements and Time of Introducing an Intercrop on the Productivity of Component Crops in Maize (zea mays 1) - Soybean (glycine max (1.) merrill) Intercropping Systems. A Thesis submitted to the Department of Crop and Soil Sciences, Kwame Nkrumah University of Science and Technology in partial fulfillment of the requirements for the degree of Masters.

[9] Morgan JA, Bending, GD and White PJ (2005) Biological Costs and Benefits to Plant-Microbe Interactions in the Rrhizosphere. J. Exp. Bot.56:1729-1739.

[10] Sarunaite L, Deveikyte I and Kadziuliene Z (2010) Intercropping Spring Wheat with Grain Legume for Increased Production in an Organic Crop Rotation. Agriculture, 97:51-58.

[11] Undie U L, Uwah D F and Attoe E E (2012) Effect of Intercropping and Crop Arrangement on Yield and Productivity of Late Season Maize/soybean Mixtures in the Humid Environment of South Southern Nigeria. J. Agr. Sci., 4: 37-50. 